\title{
A new locality of orchid Orchis purpurea Huds. in Cieszyn Foothills (Czech Republic)
}

\author{
Tomasz Beczała, Damian Chmura \& Tomasz Jonderko
}

A new locality of orchid Orchis purpurea Huds. in Cieszyn Foothills (Czech Republic). - Acta Mus. Siles. Sci. Natur. 65: 63-64, 2016.

\begin{abstract}
Orchis purpurea Huds. is protected species both in the Czech Republic and Poland. In 2014 a new locality was found in Kojkovice (district Tŕinec) in the Cieszyn Foothils near border with Poland. The only one blooming individual was observed in 2014 and 2015 but it was accompanied by other 6 orchid species, that were much more abundant, as: Orchis pallens, Orchis mascula subsp. signifera, Listera ovata, Platanthera bifolia, Cephalanthera damasonium, Neottia nidus-avis. The Kojkovice forest deserves to be protected area due to abundant occurrence of many orchids.
\end{abstract}

Key words: Ochidaceae family, Lady Orchid, strict protection, endangered species

\section{Introduction}

Orchis purpurea Huds. (Lady Orchid) is a tall, tuberous, perennial orchid with a mainly Mediterranean distribution. It is scattered sparsely through France and Central Europe and extends to Corsica and the mountains of central Italy where it is one of the most common woodland orchid species. Moreover, it occurs in southern part of UK islands, Caucasian area and mountains of Northern Africa (Jacquemyn et al. 2006, Zarzycki et al. 2014). It is protected species on the territory of the Czech Republic. It is assigned to category C2b what means that it is endangered species with approaching rarity (Grulich 2012, Danihelka 2012). In adjacent Poland, where northern border of the range of the species lies, the species is strictly protected. There are only ten isolated localities: 5 ones in Małopolska Upland, Lublin Upland (4), and the only one in Carpathian Mts (Panieńska Góra Mt.) (Mirek \& PiękośMirkowa 2008).

\section{New locality}

In April 2014 during botanical excursion in the area of small forest complex in Kojkovice village (N 49 $\left.42^{\prime} 00^{\prime \prime} / \mathrm{E} 18^{\circ} 40^{\prime} 57^{\prime}\right)^{\prime}$, which is a quarter of Trrinec town, the new locality of Orchis purpurea was found. The single individual (Fig. 1) in blooming phase was growing several meters from the forest margin within the spontaneous formed forest of approximately 20 years old. In the forest the following, tree species dominated: Tilia cordata, Betula pendula and Fraxinus excelsior. The western part of the wood is occupied by a species-rich multispecies mixed forest with the dominance of Tilia cordata resembling, in terms of species composition and physiognomy, mesophilous broad-leaved forest of the Carpinion betuli alliance (Boublik et al 2013). In turn, fragment of forest growing to the east probably is a former pasture. It is manifested by low cover of trees, high abundance of shrubs and many thermophilous plants in the ground layer.

The whole described forest complex, in spite of small area (ca. $5 \mathrm{ha}$ ), is precious site of the occurrence of orchids. Up to now, 7 species representing Orchidaceae family were encountered. In eastern part of the forest more than 10 blooming individuals of Orchis pallens L. were noted and several blooming specimens, including some with white flowers, of early-purple orchid Orchis mascula L. subsp. signifera (Fig. 1). In each of these species also vegetative stems were recorded. Moreover, in whole wood other orchid species were observed as follows: Listera ovata, Platanthera bifolia and Cephalanthera damasonium. The most frequent is Bird's-nest Orchid Neottia nidus-avis L. which most abundantly grows in more humid and western part of the forest. Both in 2014 and 2015 about 100 individuals of the species were recorded.

\section{Discussion and conclusions}

Despite very profound and thorough penetration of the area no more of Orchis purpurea specimens were found. In 2015 the same individual in blooming phase was observed again, 
however, likewise in 2014 its flower did not set seeds (D. Křenek - pers. comm.). The presented site of the species is third known locality in the north-eastern part of the Czech Republic (M. Fiedor - pers. comm.). According to Zarzycki et al. (2014) in the territory of Poland the nearest locality is $100 \mathrm{~km}$ away from the one presented in this study. Both Orchis purpurea and Orchis pallens in the Czech Republic are considered as endangered and characterized by rarity and declining trend (Grulich 2012).

The forest in Kojkovice is important refuge of orchids in the scale of the Cieszyn Foothils due to the occurrence as many as 7 species representing this family. The most serious threat to this group of plants is penetration by tourists and removal and digging up plants for gardens because of ornamental values. Futhermore Orchis purpurea grows in big shade what can be cause of lack of seeds in this plant. Authors suggest that forest in Kojkovice should be protected and some treatments as forest thinning and annual monitoring will be very advisable.
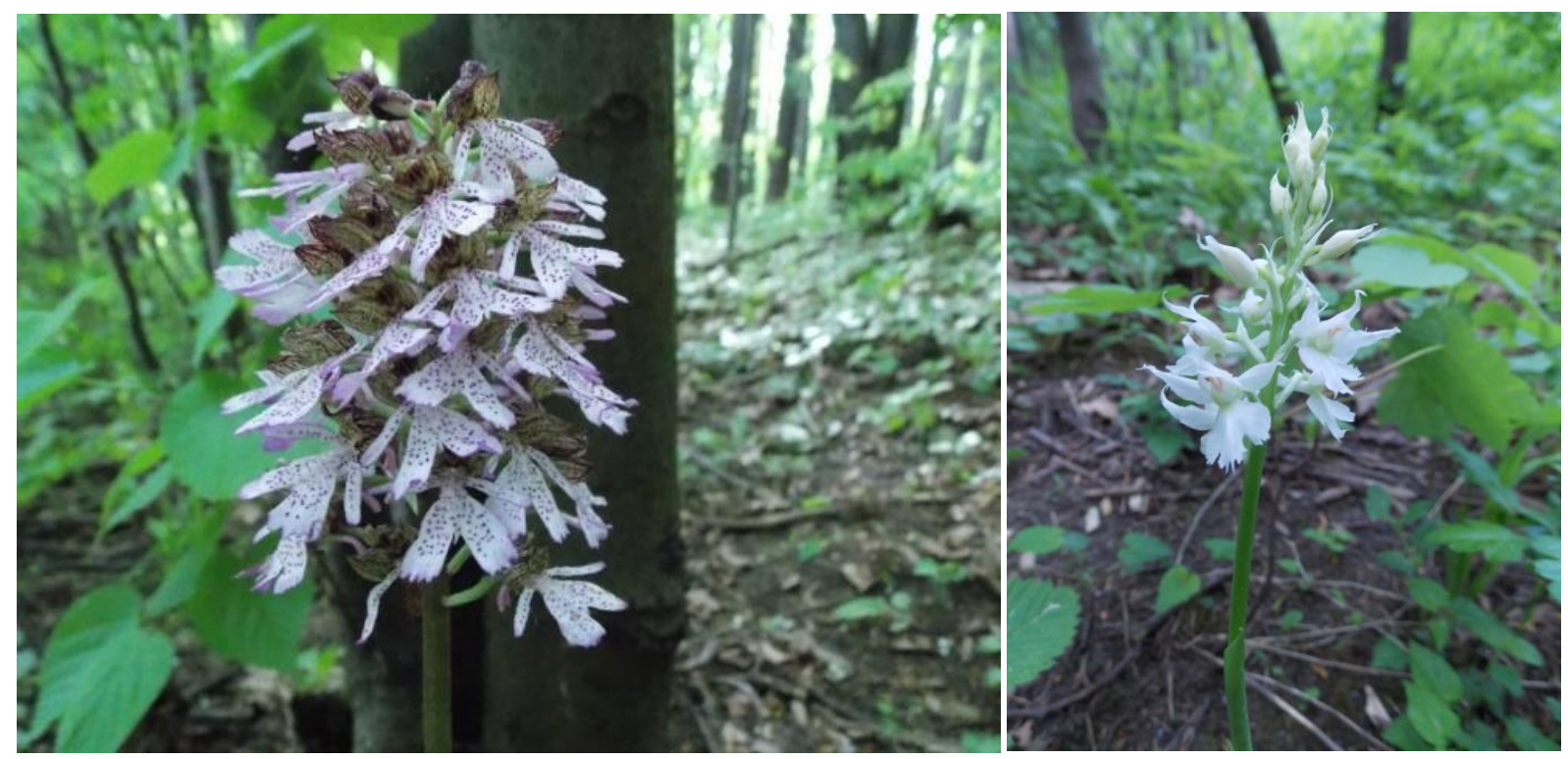

Fig 1: The inflorescence of Orchis purpurea Huds. (left) and Orchis mascula L. subsp. signifera (right) in Kojkovice locality (photos by Tomasz Jonderko).

\section{References}

Boublik K., Douda J., Hédl. \& Chytrý M. (2013): Mezofilní a vlhké opadavé listnaté lesy (CarpinoFagetea). In: Chytrý M. [ed.]: Vegetace České republiky 4. Lesní a křovinná vegetace, pp. 193-295. Academia. Praha.

Danihelka J., Chrtek Jr. J. \& Kaplan Z. (2012): Checklist of vascular plants of the Czech Republic. Preslia 84(3): 647-811.

Grulich V. (2012): Red list of vascular plants of the Czech Republic: 3rd edition. - Preslia 84: 631-645.

Zarzycki K., Fiedor M. \& Bernacki L. (2014): Orchis purpurea L. Storczyk purpurowy. In: Kaźmierczakowa R., Zarzycki K., Mirek Z. [eds] Polska Czerwona Księga Roślin. Paprotniki i rośliny kwiatowe. Wydanie III uaktualnione i poszerzone. Instytut Ochrony Przyrody PAN. 781-783.

Jacquemyn H., Brys R., Vandepitte K., Honnay O. \& Roldán-Ruiz I. (2006): Fine-scale genetic structure of life history stages in the food-deceptive orchid Orchis purpurea. - Molecular Ecology 15(10): 2801-2808.

Mirek Z. \& Piękoś-Mirkowa H. (2008): Czerwona księga Karpat Polskich. Instytut Botaniki PAN, Kraków.

Authors' adresses: Tomasz Beczała, Tomasz Jonderko, Gorecki Nature Club Association, Zalesie 12, 43-436 Górki Wielkie, Poland.

Damian Chmura, Institute of Environmental Protection and Engineering, University of Bielsko-Biala Willowa 2, 43-309 Bielsko-Biała, Poland, E-mail: dchmura@ath.bielsko.pl 